\title{
BIMBINGAN ORANGTUA DALAM MENANGGULANGI ANAK TANTRUM DI LOMBOK BARAT
}

\author{
Musawirin \\ e-mail: musawirinmusawirin@gmail.com \\ Alumni Bimbingan Konseling Fakultas Dakwah \\ dan IImu Komunikasi UIN Mataram
}

\begin{abstract}
This study aims to determine the development of tantrum children and parental guidance in tackling Tantrum Children in Kuripan Utara Village, Kuripan Lobar District. This research is a descriptive qualitative study with a case study approach. The subject of this study is the parents of children who have the behaviour of tantrums and their neighbours. Data collection techniques used are observation, interviews, documentation. The data analysis techniques are used, namely through data reduction, data presentation, and conclusion drawing. Check the validity of the data by increasing perseverance and using source triangulation. The findings of this study, namely the development of tantrum children in Kuripan Utara Village, have several developments including (a) physical development, (b) emotional development, (c) cognitive development, (d) social development. While the findings of parental guidance in dealing with tantrum children are (a) moving to another place, (b) distracting the child, (c) talking softly to the child. In this parent's guidance, the connection with the theory can produce children who will be spared from deviant behaviour when they are big.
\end{abstract}

Keywords: Guidance for Parents, Tantrum Children, Tackling. 


\begin{abstract}
Abstrak
Penelitian ini bertujuan untuk mengetahui perkembangan anak tantrum dan bimbingan orangtua dalam Menanggulangi Anak Tantrum Di Desa Kuripan Utara Kecamatan Kuripan Lobar. Penelitin ini merupakan penelitian kulaitatif deskriptif dengan pendekatan Studi kasus. Subjek penelitian ini adalah orangtua anak yang mempunyai perilaku tantrum dan tetangga-tetangganya. Tekhnik pengumpulan data yang digunakan adalah observasi, wawancara, dokumentasi. Adapun tekhnik analisis data digunakan yaitu melalui reduksi data, penyajian data, dan penarikan kesimpulan. Pengecekan keabsahan data dengan peningkatan ketekunan dan menggunkan Triangulasi sumber. Hasil temuan dalam penelitian ini yaitu perkembangan anak tantrum yang ada di Desa Kuripan Utara memiliki beberapa perkembangan diantaranya adalah (a) perkembangan fisik, (b) perkembangan emosi, (c) perkembangan kognitif, (d) perkembangan sosial. Sedangkan hasil temuan tentang bimbingan orang tua dalam menanggulangi anak tantrum adalah (a) pindah ke tempat lain, (b) mengalihkan perhatian anak, (c) berbicara halus pada anak. Dalam bimbingan orang tua ini keterkaitan dengan teori bisa menghasilkan anak yang akan terihindar dari perilaku menyimpang saat anak besar nanti.
\end{abstract}

Kata Kunci: Bimbingan Orangtua, Anak Tantrum,Menanggulangi. 


\section{A. Pendahuluan}

Anak adalah anugerah yang diberikan Tuhan kepada kita sebagai orang tua, dalam usia anak 4-6 Tahun adalah masa dimana anak masih menyesuaikan diri dengan lingkungannya sehingga ia merasa bahwa dirinya merupakan bagian dari lingkungan yang ada. Maka dari itu orang tua haruslah berhati-hati dalam memberikan contoh kepada anak dari situlah anak akan menirukannya. Karena orang tua adalah merupakan tempat pertama dalam kehidupan anak, tempat ia belajar dan menyatakan diri sebagai mahluk sosial. Dalam keluarga, umumnya anak terlibat dalam hubungan interaksi. Segala sesuatu yang dibuat keluarganya dapat mempengaruhi anak begitupun sebaliknya.

Menurut Eileen Hayes Tantrum adalah ledakan amarah yang terjadi pada usia 18 bulan sampai 6 tahun, seperti berbaring di lantai, kaki menendang-nendang, tangisan kecil untuk protes dan menangis dengan nada tinggi sebagai jenis tantrum yang paling ekstrem.

Semua anak/balita kadang akan menjadimarahdanputusasa,tetapitidak semua dari mereka menumpahkannya dengan teriakan. Sebagian yang memiliki kemampuan berbahasa dengan perkembangan baik mungkin mampu menuangkan keputus asaan mereka secara verbal; sebagian lainnya mungkin tidak memiliki tantrum, tapi menjadikan orang tuannya "gila" dengan menentang segala hal yang harus mereka lakukan. Pada sebagian keluarga, orang tua mungkin juga putus asa untuk menghindari sering terjadinya amukan tersebut Karena mereka sendiri tidak nyaman dengan emosi seperti itu dan melakukan apa saja untuk menyembunyikan. ${ }^{1}$

Orang tua bisa menjadi bingung karena permintaan si kecil yang merengek. Kadang-kadang, anak merengek untuk sesuatu, seperti "ingin es krim" atau "bacakan cerita lagi”. Kadang-kadang, hal itu berupa rengekan yang lebih umum dan suasana hati yang buruk yang mungkin lebih parah akibat rasa lapar, lelah, atau munculnya penyakit. Apapun alasannya, merengek menyebabkan kebiasaan buruk yang akan meningkat menjadi tantrum. ${ }^{2}$

Tantrum juga dialami oleh anakanak, sepertiyangbisa dilihat pada anakanak di Desa Kuripan Utara Kecamatan Kuripan Kabupaten Lombok Barat. Terutama di Dusun Perengge terdapat beberapa anak yang mengalami tantrum. Salah satu anak sebut saja

1 Eileen Hayes, Tantrum, Panduan Memahami dan Mengatasi Ledakan Emosi Anak,(Jakarta: Erlangga, 2003), 28.

2 Ibid.,43. 
Samsul (nama samaran), Samsul sering mengeluarkan tantrumnya saat bermain dengan teman sebayanya, seperti ketika melihat temannya membawa mainan dan makanan agar mainan dan makanan tersebut dimiliki olehnya, ia merebutnya dengan secara paksa, apabila ia tidak bisa memilikinya ia akan merengek kepada ibunya ataupun ayahnya, Apabila tidak dipenuhi keinginan untuk memiliki mainan tersebut maka Samsul menangis, menghentakan kakinya, memukuli ibunya dan melemparkan benda yang ada di depannya.Ibu Sumiati mengatakan: "Kalau anak saya menginginkan sesuatu dari temannya, pasti dia ingin merebutnya dengan secara paksa, apabila dia tidak mendapatkannya pasti dia menangis dan bahkan sering juga memukuli temannya, hal itu membuat saya malu dengan orang tua temanya dan juga membuat saya kualahan dengan tingkah lakunya yang seperti itu". ${ }^{3}$

Hal ini sering dilakukan oleh anak tersebut ketika menginginkan suatu benda, makanan, atauminumandengan melakukan apa saja yang ia kehendaki walaupun telah dilarang oleh orang tuanya. Bukan hanya saat bermain dengan temannya saja, namun ketika di rumah, tempat umum dia selalu

3 Wawancara dengan ibu Sumiati di Dusun Perengge Luah Desa Kuripan Utara, 7 September 2017. mengeluarkan tantrum sebagai jurus andalan agar keinginannya dikabulkan orang tuanya. ${ }^{4}$

Namun, keadaan seperti ini tidak diketahui oleh para orang tua. Sehingga anak yang mengalami gejala tersebut sering mendapat hukuman. Padahal secara ilmiah, menurut teori, gejala tersebut merupakan ekspresi anak ketika menginginkan sesuatu namun anak tersebut tidak bisa mengungkapkannya.Banyak orang tua yang tidak tahu bagaimana cara mengatasi anak yang seperti itu, sehingga anak sering mendapatkan hukuman ketika gejala tersebut terjadi. Sebenarnya, anak anak ini hanya membutuhkan perhatian, pengertian, cinta, simpati dan dukungan serta pemahaman dari orang tua agar tantrum tersebut berkurang dan dapat dikendalikan sesuai dengan umur anak.

\section{B. Bentuk Tantrum Yang Dialami Oleh Anak di Desa Kuripan}

Dalam menganalisis data tntang bentuk tantrum yang dialami oleh anak di Desa Kuripan Utara, dapat dilihat berdasarkan data yang diperoleh di lapangan.

Berbicara tentang perkembangan individu, ada dua istilah yang sering

4 Observasi 7 September 2017. 
muncul, pertama adalah istilah "perkembangan" (development) yaitu cendrung lebih bersifat kualitatif, dan berkaitan dengan pematangan fungsi organ individu. Kedua adalah istilah "pertumbuhan" (growth) yaitu cendrung lebih bersifat kuantitatif dan berkaitan dengan aspek fisik. ${ }^{5}$

Pertumbuhan dan perkembangan anak tidak bisa dipisahkan. Pertumbuhan dan perkembangan motorik dan fisik sangat berhubungan dengan perkembanga psikis anak. Dalam pertumbuhan dan perkembangan, anak akan mengalami 'golden priode' yang merupakan masa keemasan pertumbuhan dan perkembangan. "golden priode" tersebut terjadi ketika anak menginjak usia 1-3 tahun. Pada usia tersebut anak akan sangat peka dan sensitif terhadap berbagai ransangan dan pengaruh dari luar. Saat masa keemasan, anak akan mengalami tingkat perkembangan yang sangat cepat, dimulai dari perkembanga berfikir, perkembangan emosi, perkembangan motorik, perkembangan fisik dan perkembangan sosial.

Ada beberapa bentuk tantrum yang dialami oleh anak di Desa Kuripan Utara diantaranya adalah;

5 Wiji Hidayati \&Sri Purnama, Psikologi Perkembangan, (Yogyakarta: Januari 2008), 6.

\section{Menangis Keras}

Walaupun perkembangan fisik yang dialami anak yang mempunyai perilaku tantrum di Desa Kuripan Utara cukup baik dan pesat, badannya pun terlihat gemuk dan setiap kali mengikuti posyandu berat badanya selalu naik walaupun sedikit. Akan tetapi anak-anak tersebut sering menangis keras jika keinginannya tidak diturut terkadang gara-gara konflik dengan orang tua yang membuat anak frustasi.

Karakteristik emosi anak usia dini yang sering terlihat seperti emosi anak berlangsung singkat lalu tiba-tiba berhenti. Emosi anak usia dini sifatnya mendalam, tetapi mudah berganti, dan selain sifatnya terbuka juga sering terjadi. Sebagai contoh, anak kalau sedang marah dia akan menangis keras atau berteriak-teriak, tetapi kalau kemaunnya dituruti atau terpenuhi, maka tiba-tiba tangisannyaberhentidan biasanya langsung tertawa. ${ }^{6}$

Tantrum biasanya terjadi pada anak yang aktif dengan energi berlimpah. Tantrum juga lebih mudah terjadi pada anak-anak yang dianggap "sulit", dengan ciri-ciri memiliki kebiasaan tidur, makan dan buang air besar tidak teratur, sulit menyesuaikan diri dengan situasi, makanan dan orang-orang

\footnotetext{
6 Ahmad Susanto, Perkembangan Anak Usia..., 136.
} 
baru, lambat beradaptasi terhadap perubahan, suasana hati (mood) lebih sering negatif, mudah terprovokasi, gampang merasa marah atau kesal dan sulit dialihkan perhatiannya

Menurut Eileen Hayes Tantrum adalah ledakan amarah yang terjadi pada usia 18 bulan sampai 6 tahun, seperti berbaring di lantai, kaki menendang-nendang, tangisan kecil untuk protes dan menangis dengan nada tinggi sebagai jenis tantrum yang paling ekstrem. ${ }^{7}$

Jadi menangis keras adalah salah satu bentuk tantrum yang dialami oleh anak yang ada di Desa Kuripan Utara. Teori dengan realita yang ditemukan sangat sesuai dimana anak yang menangis keras adalah salah satu indikator dari tantrum bahkan itu menjadi salah satu bentuk tantrum yang ekstrim.

\section{Membentak}

Adapun bentuk tantrum yang dialami oleh anak di Desa Kuripan Utara Kecamatan Kuripan adalah membentak, anak tersebut membentak ketika keinginannya tidak dituruti sehingga dia marah terhadap orang tuanya. Adapaun bentuk tantrum yang membentak dan mengamuk ketika bertemu dengan orang yang belum pernah ia temui (orang asing),

7 Eileen Hayes, Tantrum, Panduan Memahami dan Mengatasi Ledakan Emosi Anak...,28. terkadang dia merengek sambil memarahi ibunya, terkadang juga ketika ibunya tidak ada dia memanggil dengan nada yang keras sebagai bentuk ekspresi yang diungkapkan oleh anak tersebut.

Menurut Yudrik Jahja dalam buku psikologi perkembangan mengatakan bahwa pada bayi terdapat pola emosi tertentu yang bersifat umum seperti kemarahan, ketakutan, rasa ingin tahu dengan mainan baru menjulurkan lidah, membuka mulut, memegang, kegembiraan. ${ }^{8}$

Tantrum adalah masalah perilaku yang umum dialami oleh anak-anak prasekolah yang mengekspresikan kemarahan mereka dengan tidur di lantai, meronta-ronta, berteriak dan biasanya menahan napas. Tantrum adalah bersifat alamiah, terutama pada anak yang belum bisa menggunakan kata dalam mengungkapkan rasa frustrasi mereka. ${ }^{9}$

Secara teori, anak tantrum yang mengalami perkembangan emosi di Desa Kuripan Utara sangat sesuai dengan teori yang diungkapkan oleh Yudrik Jahja bahwa pada bayi terdapat pola emosi tertentu yang bersifat

8 Yudrik Jahja, Psikologi Perkembangan, (Jakarta: Kencana Prenadamedia Group, 2011), 71.

9 Syamsuddin, "Mengenal Perilaku Tantrum Dan Bagaimana Mengatasinya Understanding Tantrum Behavior and How to Solve It", Informasi, Vol. 18, No. 02, Tahun 2013. 
amarah, ketakutan. Begitupun hasil penelitian yang dilakukan di Desa Kuripan Utara bahwa anak tantrum banyak yang mengalami ketkautan saat bertemu orang yang belum pernah ia temui (asing) dan marah jika keinginannya tidak dituruti.

Tantrum juga disebabkan oleh tekanan emosi anak, kadang-kadang anak juga merasa frustasi karena keinginan anak tidak dituruti, jadi jelas anak di desa kuripan utara yang mengalamiperkembangan emosidapat dikatakan bahwa mereka memiliki tantrum sebagian juga memiliki tantrum yang ekstrim.

\section{Memaki}

Berikut hasil penelitian tentang bentuk tantrum yang dialami oleh anak di Desa Kuripan Utara Kecamatan, seperti memaki temanya ketika kalah dalam berebutan mainan atau makanan, sebagian anak yang memilik perilaku tantrum juga terkadang membuat suasana menjadi rebut di dalam kelas PAUD Ijtihadul Mu'minin karena ketika mereka saling berebutan mainan akan terjadi perkelahian bahkan mereka sampai menangis pergi ke orang tua untuk mengadu dan pada saat orang tua tidak menghiraukan maka anak tersebut tidak segan untuk memukuli ibunya. namun mereka adalah anak yang aktif terutama dalam hal belajar.
Bentuk tantrum berdasarkan proses pembentukannya yang dapat dibedakan dalam 3 tahapan, yakni tahap pemicu (trigger), tahap respon dan tahap pembentukan. Tahap pemicu tampak pada saat anak diserang, dikritik atau diteriaki oleh orangtua atau saudara dengan sesuatu yang menyakitkan atau menjengkelkan. Kemudian, anak merespon kritikan tersebut secara agresif dan destruktif. Jika perilaku agresi yang dimunculkan oleh anak tersebut mendapatkan reward dari penyerang (attacker) dengan menjadi diam atau berhenti mengkritik, maka taktik ini dianggap berhasil. Disinilah anak akan mulai belajar membentuk perilaku tantrum sebagai senjata untuk melawan segala bentuk serangan dari lingkungannya. ${ }^{10}$

Usia 5 tahun ke atas - salah satu dari yang di atas, ditambah: a). Memaki, b). Mencela diri sendiri, c). Menyerang kakak atau adik atau teman, d). Sengaja memecahkan benda-benda, e). Mengancam. ${ }^{11}$

Bentuk tantrum yang dialami oleh anak di Desa Kuripan Utara salah satunya adalah memaki. Bentuk

10 Syamsuddin, "Mengenal Perilaku Tantrum Dan Bagaimana Mengatasinya Understanding Tantrum Behavior and How to Solve It", Informasi, Vol. 18, No. 02, Tahun 2013

11 Indana Khoiriah, Bimbingan dan Konseling Islam Dengan Pendekatan Behavior Dalam Menangani Anak Tantrum di TPQ Al-Istiqomah Siduarjo, 44. 
tantrum yang dialami oleh anak yang berumur hampir 6 tahun ini sangat sesuai dengan teori yang di yang mengatakan bahwa bentuk tantrum yang dialami anak usi 5 tahun keatas adalah memaki, mencela diri sendiri, menyerang kakak atau adik atau temannya, sengaja memecahkan benda-benda, mengancam.

\section{Merengek}

Adapun hasil penelitian tentang bentuk tantrum yang dialami oleh anak di Desa Kuripan Utara. Seperti yang sudah dipaparkan pada bab sebelumnya bahwa ada anak tantrum yang mengalami kekurangan dalam bergaul dengan teman sebayanya, walaupun anak-anak tersebut memiliki teman yang banyak namun mereka saling bertengkar satu sama lain karena ada yang diperebutkan misalnya, anak yang mempunyai perilaku tantrum tersebut ingin merebut mainan atau makanan dari temannya lalu temannya tidak ingin memberikannya maka yang dilakukan anak tantrum tersebut adalah memukul temannya lalu merengek kepada orang tuanya.

Usia 3 sampai 4 tahun - salah satu dari yang di atas, ditambah:a) Menggentakkan kaki, b) Membentak, c) Merengek,

d) Mencela,

e) Memamerkan tinjuan, f) Membanting pintu, g) Tidak sengaja memecahkan benda-benda. ${ }^{12}$

Hal ini juga dijelaskan oleh Syamsu Yusuf yang mengatakan dalam buku psikologi perkembangan anak dan remaja bahwa anak belum bersifat sosial. Dalam arti, dia belum memiliki kemampuan untuk bergaul dengan orang lain. Untuk mencapai kematangan sosial, anak harus belajar tentang cara-cara menyesuaikan diri dengan orang lain. Kemampuan ini diperoleh anak melalui berbagai kesempatan atau pengalaman bergaul dengan orang-orang di lingkunganya, baik orang tua, saudara, teman sebaya atau orang dewasa lainnya. ${ }^{13}$

Jadi hasil dari temuan di lapangan tentang bentuk tantrum yang dialami oleh anak di Desa Kuripan Utara sesuai dengan indikator yang sudah dipaparkan di atas maka jelas bahwa anak yang berumur 3 sampe 4 tahun memiliki berbagai bentuk tantrum salah satunya adalah merengek yang dimiliki oleh beberapa anak yang ada di lapangan. Dan maslah interaksi dengan teman sebayanya juga sesuai dengan teori tersebut bahwa anak belum memiliki kemampuan dalam bergaul dengan orang lain baik itu orang tua, saudara, dan teman sebayanya

12 Ibid., 44.

13 Syamsu Yusuf, Psikologi Perkembangan Anak $\Xi^{2}$ Remaja, (Bandung: PT. Remaja Rosdakarya, 2012), 101. 
sehingga mereka sering bertengkar satu sama lain untuk memperebutkan sebuah mainan atau makanan.

\section{Bimbingan Orang Tua Dalam Menanggulangi Anak Tantrum Di Desa Kuripan}

Walaupun masalah spesifik yang dihadapi orang tua berubah ketika anak tumbuh besar, pada setiap tingkatan usia, orang tua menghadapi berbagai pilihan tentang seberapa besar mereka harus merspons kebutuhan anak, seberapa besar kendali yang harus diterapkan, dan bagaimana menerapkannya, orang tua ingin anaknya tumbuh menjadi individu yang dewasa secara sosial, namun mereka mungkin merasa frustasi dalam berusaha menemukan cara terbaik untuk mencapai hal itu. ${ }^{14}$

Adapun hasil penelitian tentang bimbingan orang tua dalam menanggulangi anak tantrum di Desa Kuripan Utara Kecamatan Kuripan Lobar sebagai berikut;

Pindah ketempat lain

Adapun bimbingan orang tua dalam menanggulangi anak tantrum dengan cara pindah ketempat lain. Anak juga memiliki kebeiasaan untuk melancarkantantrumnya dengan cara

14 Jhon W. Santrock, Perkembangan Anak, Edisi-11, (Jakarta: Gelora Aksara Pratama, 2007), 164 . menangis dan merengek pada orang tua jika keinginanya tidak terpenuhi dan kadang-kadang anak menangis di tempat umum yang membuat orang tuanya merasa tidak enak karena menjadi pusat perhatian orang. Lalu cara orang tua menanggulangi sikap anak tersebut adalah dengan cara pindah ketempat lain contohnya seperti membawanya pulang atau membawanya kepada ibunya.

Menurut Eileen Hayes dalam buku Tantrum Panduan Memahami dan Mengatasi Ledakan Emosi Anak panduan bahwa orang tua harus menciptakan jarak dengan anak yang sedang mengamuk. Untuk anak yang masih kecil bisa dengan membawanya ke ruang lain yang aman, kemudian tinggalkan. Untuk anak yang lebih besar bisa dengan memintanya pergi keluardariruangan, tapibila ia menolak maka orang tua yang sebaiknya pergi. ${ }^{15}$ Seperti yang dilakukan oleh orang tua anak di Desa Kuripan Utara saat anaknya mengeluarkan tantrumnya dengan cara menangis, mengamuk dan memberontak, ketika situasi seperti itu orang tua di Desa Kuripan Utara mengatasinya dengan pindah ke tempat lain.

15 Eileen Hayes, Tantrum, Panduan Memahami dan Mengatasi Ledakan Emosi Anak,(Jakarta: Erlangga, 2003), 66. 
Orang tua juga dapat mendisiplinkan anak melalui penarikan kasih sayang. Penarikan kasih sayang adalah teknik disiplin dimana orang tua menahan atensi atau kasih sayang terhadap anak, seperti ketika orang tua menolak untuk berbicara pada anak atau menyatakan tidak suka terhadap anak. Sebagai contoh, orang tua dapat berkata "Nanti kamu ibu tinggal kalau kamu melakukan itu lagi" atau "Ibu nggak suka kalau kamu begitu.

Jadi orang tua dapat menerapkan cara untuk mengatasi perilaku anak tantrum dengan cara pindah ketempat lain yang juga dijelaskan dalam teori diatas yang mengatakan ketika anak sedang mengamuk karena keinginannya tidak dituruti maka hal yang bisa dilakukan orang tua untuk mengatasinya adalah dengan pindah ketempat lain seperti ruangan yang sepi lalu meninggalkannya tapi ketika anak masih merengek baiknya orang tua menemaninya dalam ruangan tersebut.

\section{Mengalihkan perhatian anak}

Hasil penelitian tentang bimbingan orang tua dalam menanggulangi anak tantrum dengan cara mengalihkan perhatian anak. Anak yang sering menangis, merengek dan bahkan memukuli orang tuanya saat keinginannya tidak terpenuhi / tidak dituruti tapi jika mereka sebagai orang tua dihadapkan dengan situasi seperti itu yang dilakukan adalah mengalihkan perhatian anak. Contohnya, memperlihatkan hal-hal yang yang belum pernah ia temui seperti mainan, memperlihatkan orang yang sedang lewat, memberinya makanan dan memperlihatkan benda-benda yang ada di sekitarnya.

Hal tersebut juga sesuai dengan pendapat Eileen Hayes yang mengatakan dalam buku Tantrum Panduan Memahami dan Mengatasi Ledakan Emosi Anak bahwa jika orang tua berfikir tantrum akan timbul, seringkali ada waktu untuk mengalihkan perhatian anak. Segera perkenalkan mainan baru atau menunjukan sesuatu yang sedang terjadi diluar jendela. Perkataanperkataan seperti, "Ayo lihat apakah kita bisa menemukan bata merah" atau "Aku rasa, aku mendengar bus datang. Kamu bisa mendengarnya? Ini bisa berfungsi dengan baik, terutama pada anak-anak yang lebih muda, meskipun pada usia 3 tahun mereka mungkin telah belajar untuk memahami hal itu dan tidak mudah dibohongi. ${ }^{16}$

Untuk anak batita paling muda, hingga 2 tahun, tindakan selalu lebih berartidaripadakata-kata. Memberikan

16 Eileen Hayes, Tantrum, Panduan Memahami dan Mengatasi Ledakan Emosi Anak, (Jakarta: Erlangga, 2003),64. 
alasan mungkin tak berarti. Akan tetapi sebaiknya, angkatlah dia dari depan vide oatau pindahkan ke sebuah tempat yang aman seperti kursi dorong; alihkan dia dari makanan kucing dengan biskuit. Orang tua juga bisa mendekapnya dengan erat ketika tantrum mengancam.

Anak yang mempunyai perilaku tantrum di Desa Kuripan Utara kadangkadang sulit sekali mengatasi tantrumnya. Campur tangan orang tua bahkan dapat memperburuk kemarahannya. Jadi orang tua menanggulanginya dengan cara mengalihkan perhatian anak dengan mengajaknya melakukan permainan yang telah lama tidak dilakukannya, atau perdengarkan lagulagu gembira favoritnya. Cara lain yang dapat dicoba adalah humor atau main tebak-tebakan dengan si anak.

\section{Berbicara halus pada anak}

Seperti data temuan yang sudah dipaparkan di bab sebelumnya bahwa berbicara halus pada anak untuk menanggulangi anak tantrum ternyata paling banyak dilakukan oleh ibuibu di Desa Kuripan Utara. Saat anak yang mempunyai perilaku tantrum mengamuk dan seperti menangis sambil berguling-guling di lantai ketika keinginanya tidak dituruti disaat itu seorang ibu memerankan peranannya sebagai orang tua, ia mengajaknya berkomunikasi dengan notasi yang lembut kemudian mengajaknya bermain dan bercanda.

Secara teori di jelaskan oleh Eileen Hayes dalam buku tantrumnya bahwa prang tua berbicara dengan tenang kepada anak dalam suara pelan dan membiarkannya mengetahui bahwa orang tua tidak akan menghukum atau meninggalkannya, kadang-kadang membuatnya berhenti mendengarkan atau setidaknya menekan keributan ke tingkat yang bisa ditahan. ${ }^{17}$

Tenang dan konsisten pada saat orang tua harus mengatakan "tidak", jangan terperangkap dalam perselisihan yang emosional. Ulangi ucapan dengan tenang. Tetapi jangan terjebak dengan argumen lebih lanjut.

Jadi jika orang tua berteriak maka si kecil akan membalas dengan teriakan yang lebih hebat. Namun jika orang tua dapat berbicara dengan intonasi yang halus namun mantap, hal ini akan membantu si kecil mengatasi diri. Terkadang karena terlalu halus suara yang di ucapkan, si kecil tidak dapat mendengar. Hal ini justru menguntungkan, karena biasanya ia akan terdiam berkonsentrasi pada apa yang orang tua ucapkan.

Orang tua di Desa Kuripan Utara yang memilik anak tantrum secara tidak lansung sudah menerapkan 
cara yang baik untuk menanggulangi anak mereka walaupun mereka tidak mengertitentanganakyangmempunyai perilaku tantrum. Sedangkan dampak setelah anak besar nanti bisa jadi akan menyimpang karena tidak segera untuk ditangani.

\section{Penutup}

Perkembangan anak tantrum dan bagaimana peren orang tua dalam menanggulangi anak tantrum di Desa Kuripan Utara Kecamatan Kuripan Lobar seperti beikut:Ada beberapa bentuk tantrum yang dialami oleh anak di Desa Kuripan Utara diantaranya adalah: (a) Menangis keras, (b) Membentak, (c) Memaki, dan (d) Merengek.Adapun hasil penelitian tentang bimbingan orang tua dalam menanggulangi anak tantrum di Desa Kuripan Utara Kecamatan Kuripan Lobar adalah; (a) Pindah ketempat lain, (b) Mengalihkan perhatian anak, dan (c) Berbicara halus pada anak.
Daftar Pustaka

Hayes, Eileen, Tantrum, Panduan Memahami dan Mengatasi Ledakan Emosi Anak, (Jakarta: Erlangga, 2003)

Hidayati, Wiji \& Purnama, Sri, Psikologi Perkembangan, (Yogyakarta: Januari 2008)

Jahja, Yudrik, Psikologi Perkembangan, (Jakarta: Kencana Prenadamedia Group, 2011)

Khoiriah, Indana, Bimbingan dan Konseling Islam Dengan Pendekatan Behavior Dalam Menangani Anak Tantrum di TPQ Al-Istiqomah Siduarjo

Observasi 7 September 2017

Santrock, Jhon W., Perkembangan Anak, Edisi-11, (Jakarta: Gelora Aksara Pratama, 2007)

Syamsuddin, "Mengenal Perilaku Tantrum Dan Bagaimana Mengatasinya Understanding Tantrum Behavior and How to Solve It",(Informasi, Vol. 18, No. 02, Tahun 2013)

Wawancara dengan ibu Sumiati di

Dusun Perengge Luah Desa Kuripan Utara, 7 September 2017.

Yusuf,Syamsu, PsikologiPerkembangan Anak \& Remaja, (Bandung: PT. Remaja Rosdakarya, 2012) 